\title{
INTRASITE VANCOMYCIN POWDER AS A PROPHYLACTIC ADJUVANT IN LUMBAR FUSION
}

\author{
VANCOMICINA EM PÓ NO SÍTIO CIRÚRGICO COMO ADJUVANTE NA \\ PROFILAXIA ANTIBIÓTICA DE FUSÃO LOMBAR
}

\section{VANCOMICINA TRANSTISULAR EN POLVO COMO ADYUVANTE EN PROFILAXIS ANTIBIÓTICA EN FUSIÓN LUMBAR}

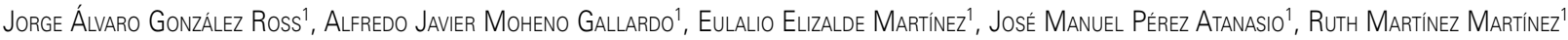

1. Hospital deTraumatología y Ortopedia U.M.A.E. “Dr. Victorio de la Fuente Narváez," Distrito Federal, México.

\begin{abstract}
Objective: To identify whether the use of prophylactic intrasite vancomycin as an adjuvant is a protective factor against deep tissue infection of the surgical site. Methods: Retrospective, descriptive, case-control study evaluating 210 patients, of whom 70 received intrasite vancomycin (case group) and 140 were controls. It was made a follow up for at least one year, reviewing the physical and electronic records. Data were tabulated in spreadsheets (Excel) including all variables and the statistical analysis was made with Epi Info ${ }^{\mathrm{TM}} 7$ to calculate the odds ratio. Results: Seven cases of deep infection occurred in the control group and none was found in the case group (odds ratio [95\% confidence interval]: 0.1262 [0.007-2.24], $P=0.1585)$. Among the predisposing factors, diabetes and surgical time were the most relevant. Conclusions: Intrasite use of vancomycin has a protective effect against deep infection in patients undergoing lumbar fusion surgery without presenting considerable side effects.
\end{abstract}

Keywords: Vancomycin; Spinal fusion; Surgical wound infection; Antibiotic prophylaxis.

\section{RESUMEN}

Objetivo: Identificar si el uso de vancomicina transtisular profiláctica como coadyuvante es un factor protector contra la infección de tejidos profundos del sitio quirúrgico. Métodos: Estudio retrospectivo, de carácter descriptivo, con casos y controles que evaluó 210 pacientes, de los cuales a 70 se les aplicó vancomicina (grupo de casos) y 140 controles. Realizado un seguimiento de al menos un año, revisando el expediente físico y electrónico. Los datos fueron tabulados en hojas de cálculo (Excel) incluyendo todas las variables, y aplicamos el análisis estadístico con Epi Info ${ }^{T M}$ 7, para calcular la razón de momios. Resultados: Se presentaron 7 casos de infección profunda en el grupo control, ninguno en el grupo de casos (razón de momios [intervalo de confianza del 95\%]: 0,1262 [0,007 a 2,24], p = 0,1585). Entre los factores predisponentes encontramos que la diabetes y el tiempo quirúrgico fueron de mayor relevancia. Conclusiones: El uso de vancomicina transtisular ejerce un efecto protector contra la infección profunda en pacientes sometidos a cirugía de fusión lumbar sin presentar efectos colaterales de consideración.

Descriptores: Vancomicina; Fusión vertebral; Infección de herida operatoria, Profilaxis antibiótica.

\section{RESUMO}

Objetivo: Identificar se o uso de vancomicina profilática como adjuvante no sítio cirúrgico é um fator de proteção contra a infecção dos tecidos profundos. Métodos: Estudo retrospectivo, descritivo, de caso-controle, que avaliou 210 pacientes, dos quais 70 receberam vancomicina no sítio cirúrgico (grupo caso) e 140 eram controles. Foi feito o acompanhamento por pelo menos um ano, revendo os registros físicos e eletrônicos. Os dados foram tabulados em planilhas (Excel), incluindo todas as variáveis, e a análise estatística foi realizada com o Epi Info ${ }^{T M} 7$ para calcular as razões de probabilidade. Resultados: Foram encontradas 7 ocorrências de infecção profunda no grupo controle e nenhum no grupo de casos (razão de probabilidades [intervalo de confiança de 95\%]: 0,1262 [0,007-2,24], $P=0,1585$ ). Entre os fatores predisponentes, o diabetes e o tempo cirúrgico foram os mais relevantes. Conclusões: O uso de vancomicina no sítio cirúrgico exerce efeito protetor contra a infecção profunda em pacientes submetidos à cirurgia de fusão lombar sem apresentar efeitos colaterais importantes.

Descritores: Vancomicina; Fusão vertebral; Infecção da ferida operatória; Antibioticoprofilaxia.

\section{INTRODUCTION}

Current indications for lumbar spine fusion include spinal deformity, instability, and pain. ${ }^{1}$ Deep tissue infection following spine surgery is a potential and devastating complication. Deep tissue infection from spine surgery is associated with higher morbidity, mortality, and health care costs. ${ }^{2}$ Despite increasing knowledge and advances in prophylactic practices, surgical site infections are one of the most common complication in surgery. ${ }^{3}$

The Center for Disease Control and Prevention (CDC) classifies surgical site infections as either incision or organ/space. Those related to incisions are sub-classified as those involving only the skin and subcutaneous tissue and those involving the deep tissues of the incision (muscle, fascia, for example). Organ/space infections involve any part of the anatomy, other than the incision, that was opened or manipulated during the surgical procedure. ${ }^{4}$ 
Surgical site infection (SSI) is one of the most common and most devastating complications of spine surgery. ${ }^{5}$ Its incidence varies depending on several factors, and it is estimated that between $2.8 \%$ and $11.9 \%$ of patients who undergo spine surgery contract an SSI, despite the implementation of conventional prophylactic strategies. The patients affected by these infections have longer hospitalization times and work disability, diminished quality of life, and their general outcomes compare unfavorably with those of patients who do not suffer these complications. ${ }^{6}$

The administration of intravenous antibiotics is perhaps the most used strategy for the prevention of SSI. The most recent clinical practice guidelines from the Antibiotic Prophylaxis Work Group of the North American Spine Society recommend the systematic administration of intravenous prophylaxis. However, it has been shown that the magnitude of SSI is relatively low which has led to a search for other alternatives. ${ }^{7}$

Antibiotics in powder form placed directly in the surgical wound prior to closure has proved to be one of the effective means of reducing postoperative deep tissue infections. ${ }^{8}$ (Figure 1)

In theory, depositing the antibiotic in powder form directly in the site of the operation (intrasite) achieves the highest concentration of the antibiotic in the wound. ${ }^{7}$

The local use of vancomycin powder has resulted in a significant reduction in postoperative infections in patients with spinal instrumentation. ${ }^{9}$ No adverse effects attributable to the use of vancomycin in powder form have been reported. ${ }^{9,10}$ However, the local use of vancomycin powder does not reduce the incidence of postsurgical infection beyond 30 days in patients following spine surgery for deformity. ${ }^{6}$

The application of vancomycin in powder form in the reconstruction of the surgical wound is an innovative trend for the prevention of surgical site infection and continues to gain the support of spine surgeons for its low cost, availability, ease of application, good safety profile, and apparent effectiveness. ${ }^{11}$

Even though the pharmokinetic properties of vancomycin applied to the surgical site is a very attractive method of prophylaxis, its adverse effects present a significant inconvenience. Intravenous application has been associated with anaphylactic reactions, arterial hypertension, nephrotoxicity, ototoxicity, and promoting resistance to antibiotics. However, its safety profile when applied topically is not yet totally understood. ${ }^{12,13}$

On the other hand, several studies have described the mecha-

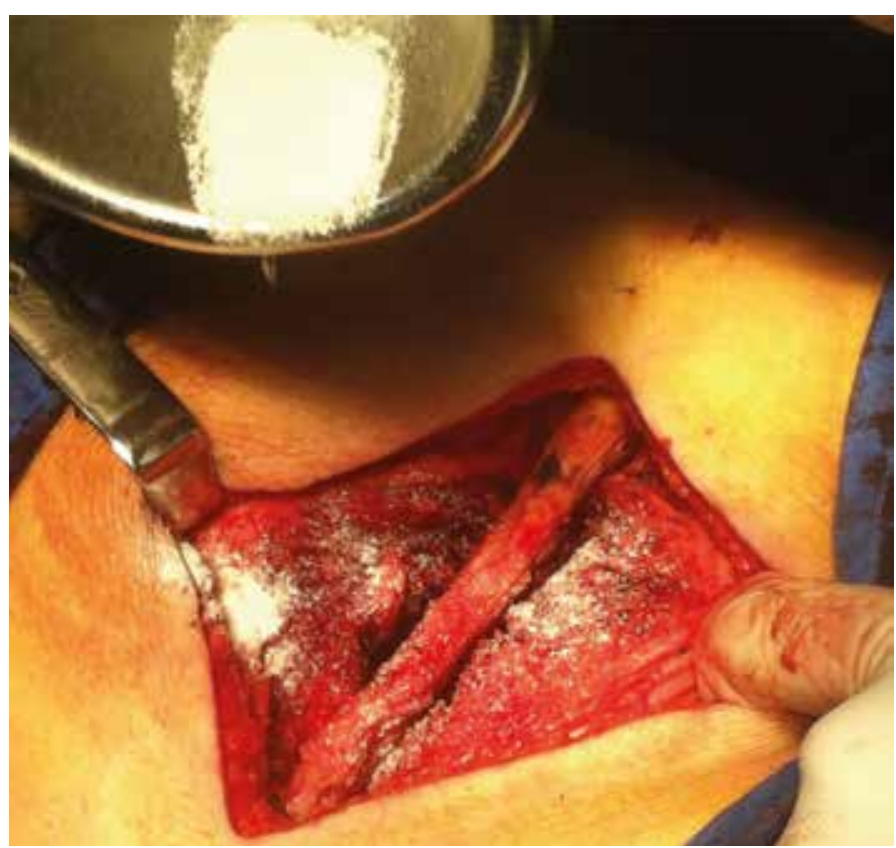

Figure 1. Photograph of the application of $1 \mathrm{~g}$ of vancomycin powder to the surgical wound site after cleansing and just prior to closure of the wound. nisms by which vancomycin can interfere with osteoblast maturation and function, which could change the physiological processes involved in bone fusion. For this reason, several authors maintain that high local concentration of vancomycin inside the surgical site can be associated with a higher risk of pseudoarthrosis (or lack of union). ${ }^{14,15}$

However, in the meta-analysis by Alcalá-Serra et al. ${ }^{11}$ reviewing three studies with 2156 patients regarding the risk of nonunion, they found an incidence of $0.7 \%$ in the treated group compared to $0.9 \%$ in the control group. They also comment that there are no recorded incidents or complications related to the application of vancomycin in the surgical wound in any of the 1,437 subjects treated from 6 observational studies. Thus, it was not possible to conduct a comparative analysis.

We perform between 850 and 950 surgeries annually. An average of 160 spinal instrumentations are performed per year. The overall infection rate is $1.94 \%$ and infection rate amongst lumbar fusions was $6.54 \%$ during the year 2013 .

Based on this, we believe that the use of intrasite vancomycin as a prophylactic adjuvant will be offer protection against deep tissue infection at the surgical site in at least $50 \%$ of cases. ${ }^{10}$

\section{MATERIAL AND METHODS}

We conducted a retrospective study of cases and controls. Group A (cases) was treated with $1 \mathrm{~g}$ of vancomycin in powder prior to closure of the surgical wound, in conjunction with first-generation cephalosporin. Group B (controls) was treated exclusively with intravenous first-generation cephalosporin. In both groups, $1 \mathrm{~g}$ of first-generation cephalosporin was used 1 hour before surgery and three doses of $1 \mathrm{~g}$ every eight hours following surgery. We used the following inclusion criteria: patients registered with Mexican Social Security (IMSS), adult patients of both sexes who underwent primary lumbar instrumentation. Exclusion criteria were: patients with body mass index $>40 \mathrm{~kg} /$ $\mathrm{m}^{2}$, patients with prior lumbar surgeries, patients with histories of allergies to cephalosporin and vancomycin, foreign patients, and patients with rheumatoid arthritis. Patients selected must have had at least one year of postoperative follow-up.

Among the variables studied were sex, age, diagnosis, body mass index (BMI) $(20-25,26-30,31-36,36-40)$, number of levels instrumented $(1,2,3,4$, and $>4)$, surgical time $(<4$ hours or $>$ 4 hours), trans-surgical bleeding (<1000cc or $>1000 \mathrm{cc})$, agent isolated, and the presence or not of deep tissue infection.

We performed the calculation of the sample size using the Hulley tables for a dichotomous variable (deep tissue infection) considering the following parameters: confidence interval of 95\%, expected rate of infection of at least $50 \%$ in agreement with the study hypothesis, and an amplitude interval of $25 \%$. With these, we obtained a total number (n) of 61 cases and 122 controls (two controls for each case) with a total number of 183.

The study was reviewed and approved by the Bioethics and Research Committee and was assigned the registration number R-2015-3401-6.

\section{RESULTS}

There were 78 patients who had vancomycin applied at the surgical site, 5 of whom were disqualified because of prior lumbar surgeries and 3 because of histories of rheumatoid arthritis. We obtained 70 cases who received intrasite vancomycin and 140 control cases, for a total of 210 patients. The average age was 56 years with $65 \%$ of the population between 50 and 70 years of age. (Table 1) The distribution by sex was equal with $48 \%$ men and $52 \%$ women. $70 \%$ of the patients had BMl between 26 and $35 \mathrm{~kg} / \mathrm{m}^{2}$. (Figure 2) One gram of vancomycin in powder form was administered intrasite in the 70 cases. There were 7 cases of deep infection in the control group and none in the study group (odds ratio [confidence interval of 95\%]: 0.1262 [0.007-2.24], $p=0.1585)$. In the case group, we found one case of seroma plus dehiscence of 
the wound with a positive initial culture, however, as a result of the surgical findings reported, a negative postoperative culture, and a favorable evolution.

The microorganisms found were S. aureus 14\%, S. epidermidis 14\%, E. Coli 28\%, and MERSA 42\%. (Figure 3) One of the cases of MRSA also showed resistance to vancomycin. The case of infection by S. Epidermidis was reported as mixed with A. Baumanii. The risk of deep infection in the control group was $8.2 \%$ in diabetic patients versus $2.31 \%$ in patients without diabetes (odds ratio [confidence interval of 95\%]: 3.72 [0.79 - 17.42], $p=$ $0.0943)$. Surgical time longer than 4 hours also showed to be a positive factor for the presentation of deep infection (odds ratio [confidence interval of 95\%]: 7.6 [0.42 - 134.74], $p=0.1676)$. There was a higher incidence of seromas in the case group (odds ratio [confidence interval of 95\%]: 2.0294 [0.27 - 14.71], $p=0.4839)$, only one of which required surgical drainage. When we performed the proportion test to confirm the hypothesis, we found that the rate of deep tissue infection dropped from $6.54 \%$ to $0 \%(p=0.0269)$.

Table 1. Distribution of the population by age group.

\begin{tabular}{c|c|c|c|c|c|c|c|c}
\hline & \multicolumn{5}{|c|}{ Age group } & Total \\
\hline & $>20-30$ & $>30-40$ & $>40-50$ & $>50-60$ & $>60-70$ & $>70-80$ & $>80-90$ & \\
\hline Frequency & 4 & 11 & 42 & 78 & 58 & 12 & 5 & 210 \\
\hline Percentage & $2 \%$ & $5 \%$ & $20 \%$ & $37 \%$ & $28 \%$ & $6 \%$ & $2 \%$ & $100 \%$ \\
\hline
\end{tabular}

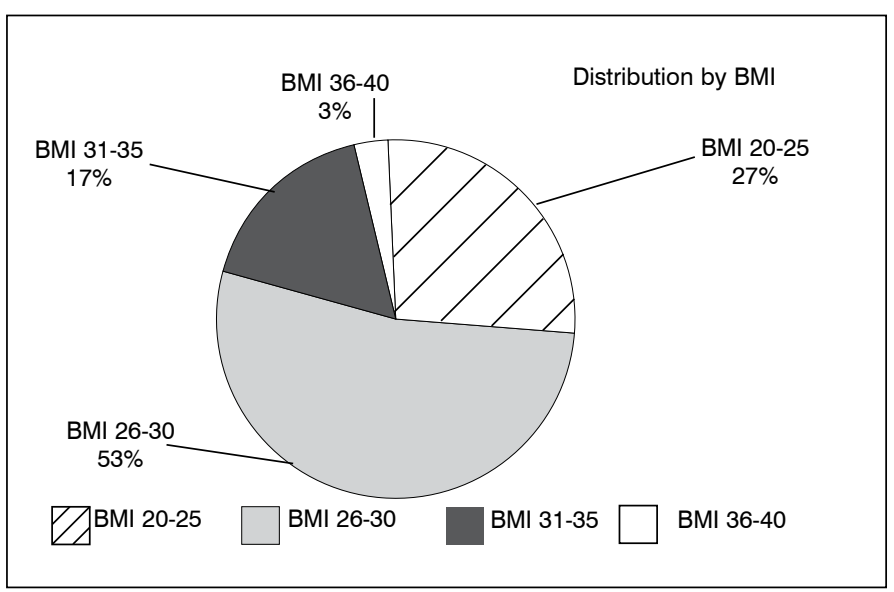

Figure 2. Distribution of the 210 patients by body mass index. $70 \%$ of the study population were defined as overweight or grade 1 obese.

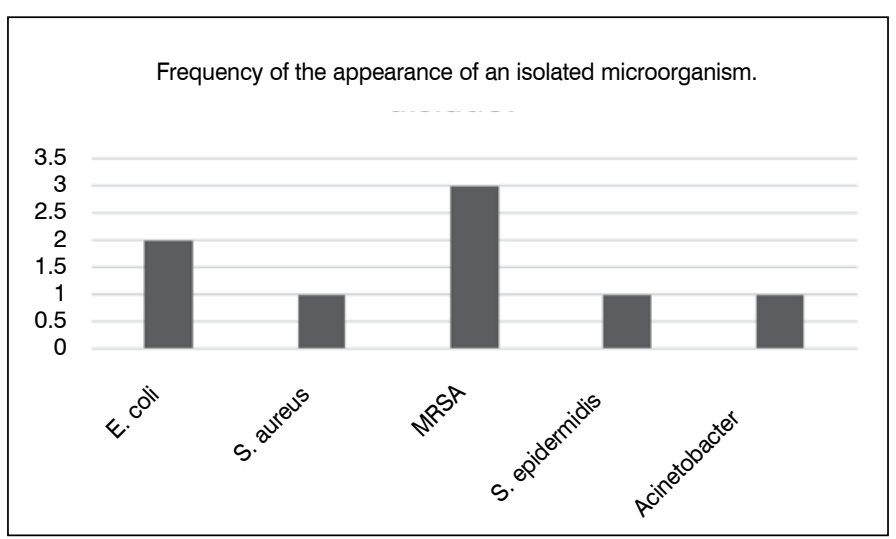

Figure 3. Frequency of the appearance of isolated microorganisms. In one case, both $\mathrm{S}$. epidermidis and Acinetobacter baumanii were present.

\section{DISCUSSION}

The application of vancomycin in powder form in the reconstruction of surgical wounds is an innovative trend for the prevention of surgical site infections and has gained increasing support among spine surgeons due to its low cost, availability, ease of application, good safety profile, and apparent effectiveness. ${ }^{11}$

In the study by Strom et al. ${ }^{10}$ they reported a reduction in the rate of infection from $10.9 \%$ to $2.5 \%$ without identifying complications attributable to the administration of vancomycin. In our study, we found a greater reduction in the rate of deep tissue infections, from $6.54 \%$ to $0 \%(p=0.0269)$.

As has been seen in various publications, we also found a higher incidence of seromas (Figure 4) in the case groups, although not statistically significant.

Despite the fact that the protective factor of the vancomycin was not statistically significant, we found a strong clinical association between the application of vancomycin in the surgical site and a reduced rate of infection, which is statistically significant if the proportion test is performed with $p \leq 0.05$. We determined that diabetes and surgical time had an important impact as predisposing factors for infection of the surgical site.

The main limitation of our study was the sample size, even with two years of experience, given that the use of vancomycin in powder form has only been used for a short period of time in the clinical department and few doctors use it routinely in patient prophylaxis. However, little by little its acceptance and use are increasing.

A prospective, controlled, randomized study with more patients is needed to obtain statistically significant results.

In the meta-analysis of Bakhsheshian et al., ${ }^{16}$ the use of vancomycin is not advised because of the complications related to its use. However, these reports are related to the systemic use of vancomycin. Meanwhile, in other publications there is no statistically significant difference for these complications. For this reason, we think that there needs to be an adjustment made to consider the means of application in the statistical analysis, as we have done in this study. Regarding the question of an increased incidence of pseudoarthrosis, we cannot address this in this study because of it design and its limitations, and we plan to investigate this in the next study with long-term follow-up.

We think that, for patients at high risk of infection with surgical time longer than 4 hours and with pre-existing diseases like diabetes, it is wise to consider the application of vancomycin in powder to the surgical site and include it in the surgical protocol.

In our study, we suspect that tobacco use has a large impact, taking into account the microvascular damage that it produces and the consequent limitations on penetration of the systemic antibiotic at the surgical site. We think that conducting a study with a greater number of patients in a way focused on defining the patients' tobacco use index could corroborate this suspicion.

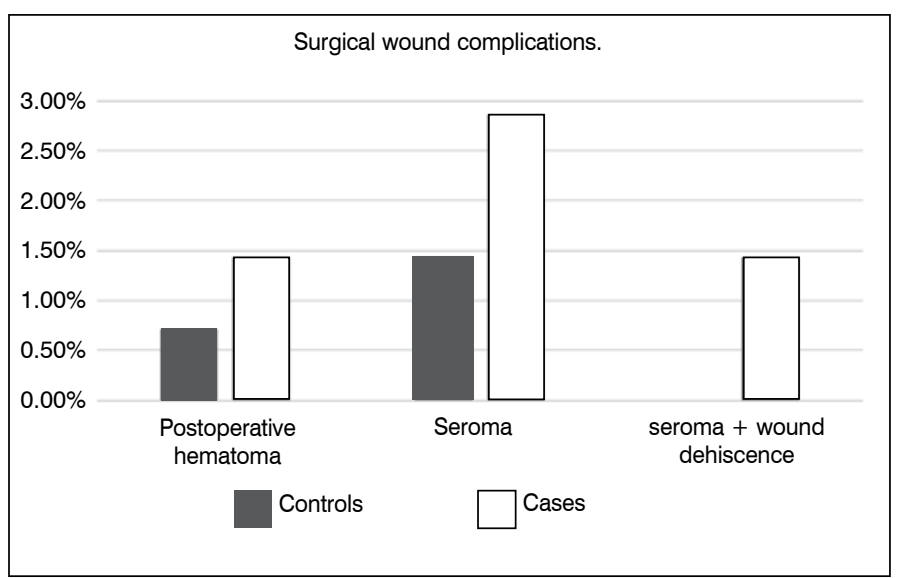

Figure 4. Incidence of surgical wound complications. Higher incidence was found in the vancomycin group. The case of seroma + wound dehiscence. 
The presence of a case with a vancomycin-resistant MRSA culture, something we had not seen reported in other publications, caught our attention.

\section{CONCLUSIONS}

The use of intrasite vancomycin produces a protective effect against deep infection in patients who underwent lumbar fusion surgery without presenting secondary effects of interest. It may be considered a viable, cost-effective, readily available option in antibiotic prophylaxis, particularly in high-risk patients and patients with surgical times longer than 4 hours.

All authors declare no potential conflict of interest concerning this article.

AUTHOR CONTRIBUTIONS: Each author made significant individual contributions to the development of the manuscript. JAGR: study conception and design, data analysis and interpretation. AJMG: critical revision, conception and design. EEM and RMM: critical revision. JMPA: critical revision, data analysis and interpretation.

\section{REFERENCES}

1. Joseph SA, Brandoff JF, Menkowitz M, Shea JO, Neuwirth MG. Lumbar spine fusion : types, principles, and outcomes. Neuroserg Q 2008;18(1):34-44.

2. Schuster JM, Rechtine G, Norvell DC, Dettori JR. The influence of perioperative risk factors and therapeutic interventions on infection rates after spine surgery: a systematic review. Spine (Phila Pa 1976). 2010;35(Suppl 9):S125-37.

3. Savage JW, Anderson P a. An update on modifiable factors to reduce the risk of surgical site infections. Spine J.; 2013;13(9):1017-29.

4. Horan TC, Gaynes RP, Martone WJ, Jarvis WR, Emori TG. CDC definitions of nosocomial surgical site infections, 1992: a modification of CDC definitions of surgical wound infections. Am J Infect Control. 1992;20(5):271-4.

5. Calderone RR, Garland DE, Capen DA, Oster $\mathrm{H}$. Cost of medical care for postoperative spinal infections. Orthop Clin North Am. 1996:27(1):171-82.

6. Martin JR, Adogwa O, Brown CR, Bagley CA, Richardson WJ, Lad SP, et al. Experience with intrawound vancomycin powder for spinal deformity surgery. Spine (Phila Pa 1976). 2014:39(2):177-84.

7. Molinari RW, Khera OA, Molinari WJ 3rd. Prophylactic intraoperative powdered vancomycin and postoperative deep spinal wound infection: 1,512 consecutive surgical cases over a 6-year period. Eur Spine J. 2012;21(Suppl 4):S476-82.

8. Hill BW, Emohare O, Song B, Davis R, Kang MM. The use of vancomycin powder reduces surgical reoperation in posterior instrumented and noninstrumented spinal surgery. Acta Neurochir (Wien). 2014;156(4):749-54.
9. Kim HS, Lee SG, Kim WK, Park CW, Son S. Prophylactic intrawound application of vancomycin powder in instrumented spinal fusion surgery. Korean J Spine. 2013;10(3):121-5

10. Strom RG, Pacione D, Kalhorn SP, Frempong-Boadu AK. Decreased risk of wound infection after posterior cervical fusion with routine local application of vancomycin powder Spine (Phila Pa 1976). 2013;38(12):991-4.

11. Alcalá-Cerra G, Paternina-Caicedo AJ, Moscote-Salazar LR, Gutiérrez-Paternina JJ, Niño- Hernández LM. Application of vancomycin powder into the wound during spine surgery: systematic review and meta-analysis. Rev Esp Cir Ortop Traumatol. 2014;58(3):182-91.

12. Mariappan R, Manninen $P$, Massicotte EM, Bhatia A. Circulatory collapse after topical application of vancomycin powder during spine surgery. J Neurosurg Spine. 2013;19(3):381-3.

13. Gans I, Dormans JP, Spiegel DA, Flynn JM, Sankar WN, Campbell RM, et al. Adjunctive vancomycin powder in pediatric spine surgery is safe. Spine (Phila Pa 1976). 2013;38(19):1703-7.

14. Rathbone CR, Cross JD, Brown KV, Murray CK, Wenke JC. Effect of various concentrations of antibiotics on osteogenic cell viability and activity. J Orthop Res. 2011:29(7):1070-4.

15. Ketonis C, Barr S, Adams CS, Shapiro IM, Parvizi J, Hickok NJ. Vancomycin bonded to bone grafts prevents bacterial colonization. Antimicrob Agents Chemother. 2011;55(2):487-94

16. Bakhsheshian J, Dahdaleh NS, Lam SK, Savage JW, Smith ZA. The use of vancomycin powder in modern spine surgery: systematic review and meta-analysis of the clinical evidence. World Neurosurg. 2015;83(5):816-23. 